\title{
Information society and civic education of the personality
}

\author{
Larisa N. Belenchuk ${ }^{1, *}$ and Svetlana S. Nevskaya ${ }^{1}$ \\ ${ }^{1}$ ISED RAE, Laboratory of History of Pedagogy and Education, 105062, Moscow, Russia
}

\begin{abstract}
The article reveals the interdependence of information society development and civic education, shows the relationship of these processes. Also, the main parameters of a modern society relating to globalization and the impact on education of the person are the object of analysis. With the reference to the example of the leading Soviet pedagogy educator, A.S. Makarenko, an attempt is made to identify the main features of civil identity formation within the national educational institutions, especially in the national tradition of human socialization, the main of which is a combination of legal education with the moral formation of the person.
\end{abstract}

Currently, in our country the civic education of the personality becomes one of the main tasks of the school. It's about the public interest and state in this issue that testify the materials of the meeting of V.V. Putin with the community concerning youth patriotic upbringing, the meeting held on 12 September 2012, soon after the reelection of V.V. Putin as President, and thus indicating importance of the issue.

And to be clear - the question of civic education is located, no more or less, at the forefront the very existence of Russia: "It's on the way we educate young people that depends whether Russia will be able to preserve and augment itself. Can it be a modern, forwardlooking, economically efficient state, and at the same time not losing itself as a nation, not losing its identity in a very difficult situation today?"

This problem, according to V. V. Putin, seems especially significant in the information era: "As witnesses historical experience - including our own -, cultural awareness, spiritual, moral values, value codes all this is the fierce competition sphere, sometimes the object of open information warfare, at least on the level of confrontation, not aggression - but for sure it's the question of well-orchestrated propaganda attacks. And it is no way phobias. I invent nothing here. It is really as it is. This is at least a form of competition.

Attempts to influence the views of the whole nations, desire to subordinate them to one's will, to impose system of foreign values and concepts - it is an absolute reality, as well as the struggle for mineral resources faced by many countries, including our country" [1].

Thus, the task of civic education becomes crucial in our time. However, it was important in all ages, and the leaders of the country, acting for the benefit of it, as well as educational community, are well aware of this. Thus, the theme of civic education runs through all the work of K.D. Ushinskii, V.G. Belinskii, N.I. Pirogov, V.Ya. Stoyunin and other our outstanding educators and thinkers. Civic education in the Russian tradition can never be abstract, it is always based on patriotism, on the awareness of individuals to be part of their people. Many of the words of our great teacher K.D. Ushinskii could be soundly repeated today: "We are positively convinced that the poor state of our finances, frequent lack of success of our large industrial enterprises, the failure of many of our administrative measures, horse-drawn transporting along the railways, our impassable roads, our bursting stocks, primary affairs under the control of incompetent fools and technicians scientists with nothing to do, absurd fantasies of our youth and not less absurd fears that are so cleverly used by people fishing in troubled waters - all these diseases that are devouring us, depend more on our ignorance of our country, than on the ignorance of ancient languages. We are convinced that all of these diseases and many others would be overcome to great extent, if in Russia is raised the general level of knowledge about Russia, if we ensure that our youth, ending course of study, knows about half of the world Russia at least as many positive facts as a 10-year-old Swiss, ending the course of the primary school, knows about his small Switzerland." Ushinskii put in the basis of civic education the upbringing in national spirit, the knowledge of the Motherland, and only on this basis - in the spirit of universal brotherhood of people [2].

Speaking of civic education as the basis for the organization of the information field in Russia, it should be noted that the setting up of world-wide overall information space is certainly a positive factor in education. Many phenomena, facts, books became available to the widest layers of the population. However, here in all growth there is the problem of the selection of the material, its system analysis, critical thinking. "Separation of wheat from the chaff." This process takes place on the basis of existing world view, values, national preferences. In the case of affecting these very foundations, the process of assimilation of the material will be different.

Now let's see, what are exactly the values that we are

\footnotetext{
*Corresponding author: ya.lbel@yandex.ru
} 
offered as the basis of education, first of all, within the format of the information space. The most important elements of the functioning of the major Western societies, from the 2 nd half of XIX century, became civil society and universal education. But from the 60-70-ies of the XX century, their existence has come into conflict with the interests of the global capital tip [3]. From now on a down-shifting has been taking place in the development models of leading countries - from industrial and technological development to information and communication sphere, since the latter enables to establish a strict control over the people. In the USA, at this same time the educational standards were deliberately lowered, and "university education, then still the heart of the American Dream, was converted into low-quality mass production." The number of students in American universities at the same time has increased more than 2 times, which was a form of hidden unemployment - says a prominent American political scientist and economist William Engdahl [4].

Civil society has been losing gradually its field of activities, and education is the object of reshaping, which consists in isolating the elite segment for the upper crust and sharply reducing the average level for all others. At the same time the idea that education is a service provided by the state to society introduced into the public consciousness. This terminology penetrates all major government documents regulating the development of the school. And if it is a kind of service, so competition is needed as at any service market, and it is not a fact that it can be carried out more effectively by government agencies, and perhaps the contrary - by private business, and most likely - by corporations. Currently (since 2013) the developing of the Trade in Services Agreement (TISA), which involves more than 50 countries, has been taking place. Negotiations are being held in secrecy outside the WTO. TISA calls into question the most important social functions of the state, including education [5].

Powerful information pressure can be resisted through targeted civic education based on local traditions, the way that different states are trying to follow with varying degrees of success.

In the 90 - zero years of XX-XXI century, many of us imagined that the knowledge about the Western "democracies" can help our young people to build up their own relationship with the state and society. On this wave the programs, training aids and materials collections were compiled. Thus, A.F. Nikitin, the author of teaching complex for the legal education of schoolchildren, insisted in his publications on the need of political and legal socialization of schoolchildren on the basis of indisputable social values.

As regards the essence of civicism A.F. Nikitin wrote the following: "In our opinion, it is the unity of political, legal and moral in the subjective-personal form, it is the feeling of being an active member of society, loyal to the political and legal basis of the existence of this specific state." The ability to be a citizen - this is to offer himself to the opinion of the whole country," - wrote F.M. Dostoevsky. Civic education is one of the real ways to achieve the consent within the Russian society, when political, national and other differences could not prevent a broad social consensus on the main issues and the outer questions of the life of the country. In this connection, it is advisable to raise a question of the creation of the course "Civic Education" for secondary school, in adequacy to those existing in many civilized, democratic country [6]. This passage clearly characterizes the vector of educational thought in this period.

However, even at that time the doubt has arisen with the part of scientists questioning the validity of such borrowing from Western European school practice, and of the affirming that the legal knowledge must be in the center of civic education system. For example, in the article "Upbringing of young citizen - an acute problem of modern school education" (2005) professor N.I. Eliasberg noted that the "Law of the Russian Federation "On Education" emphasizes the priority of upbringing; in the preamble of the law it's determined that education is upbringing and training in the interests of man, society and state" however, "in the post-Soviet period it was not possible to create a complete education and school system that focuses on the formation and development of personality, ready to live in a civil, democratic society and a lawful state, personality which is free, selfrespecting, humanistic-oriented, tolerant, socially active, characterized by civicism and patriotism" [7]. The content of education is focused on knowledgeaccumulation model and fails to emphasize "moral value orientations, moral principles, etc." which "are generated not only and not so much through the transfer of knowledge as through the experience and expertise of specially organized activity" [7]. It turns out that we have not only gained nothing new in terms of civic education, but also lost a lot. For this purpose, according to the professor, "it is necessary to define a set of measures that would stimulate the creation in each school an integrated system of civil-law education, covering both the learning process, so to extracurricular forms of work with students"; "allocation in the curriculum of primary (grades 1-4) and elementary school (grades 5-9) of one hour per week on civil status, clearly focused on the moral and legal education of schoolchildren, their positive socialization and crime prevention ... These courses should become civil vertical aimed at upbringing of the citizens" [7]. Next N.I. Eliasberg explains features of extracurricular forms, which would give children not just knowledge, but also the experience of civil life.

Such an experience in civil-law education and upbringing of young generation is of paramount importance. But we should not forget the historical experience that can't be copied, but that gives us the right direction for future work. An example of a successful upbringing of a citizen of the Fatherland is a school of A.S. Makarenko. There has not yet been in the latest period of world practice the example equal by efficiency to this case of moral and legal upbringing of the young generation. The pedagogue created the chart of the colony - firmly established rules, mandatory for students and for teachers, set forms of discipline that do not allow arbitrariness of neither person, and reached the exact conformity between orders to their execution.

This is A.S. Makarenko position on the use of 
methods of reward and punishment that particularly attracted teachers in those years. He believed that the punishment which infringes the honor and dignity of the person indeed spoils the person. But the punishment aimed to protect the values and norms of the team, the security of the person against violence, is just and necessary. Forgiveness has a devastating impact on interpersonal relationships in the community and leads to degradation of the collective. Waiver of punishment makes teachers vulnerable to aggressive behavior of children. Whatever punishment is: arresting, when the pupil had to stay for two hours at the office of A.S. Makarenko, or excluding a pupil from a colony - it should always reflect the reasonable request of the collective to all the participants of the pedagogical process. These ideas are in general contrary to the spirit of the leftist school of 20-ies [8], when N.C. Krupskaya, P.P. Blonskii, S.T. Shatskii opposed the use of sanctions. School charter of the 20-ies put a ban on all forms and types of punishment of children. It was believed that children disciplined misconduct was provoked only by teachers' bad work, and it was sufficient to eliminate the factors causing a negative behavior to make a child behave normally. This position is based on the concept of "free education", which founder is considered to be JeanJacques Rousseau.

N.C. Krupskaya categorically opposed the so-called children's courts. As regards A.S. Makarenko he introduced a friendly court, emphasizing its democratic character, by the charter of the country named FED (the Charter of the Commune named after Dzerzhinskii). Court sessions were hold openly, in the presence of teachers and pupils. Court elected for three months of four pupils, the fifth member being a teacher. The function of monitoring the implementation of the decision of the court was entrusted to an executor elected by the general meeting.

N.K. Krupskaya opposed the "Code" of punishments, which itemized "penalties" imposed on students for misconduct. A.S. Makarenko, in turn, considered it possible to execute the code ... " [9]. We can say that pedagogy by A.S. Makarenko returned to the historical traditions of Russia, breaking anarchist, leftist, Western centric excesses which were typical for the first two decades of Soviet rule. It was the priority of collective over personal that returned once more at the forefront (the civic consciousness consists mainly in the ability to subordinate personal interests to those of society, nation and state), as well as the role of discipline in combination with democratic, social principles.

Unfortunately, so far pedagogical system of A.S. Makarenko has not found a proper theoretical understanding. One of the efforts was made in 2008 at a scientific conference in Samara by A.A. Frolov who prepared the report "A.S. Makarenko and L.I. Petrazhitskii: the ratio of law and morality (pedagogical aspect)", in which he suggested the need to study the legacy of an internationally recognized educator in connection with the development by the latter of new social pedagogy, which is based on the ratio of the right and morality. This is a very profound thought. In the national consciousness a law can't exist without justice, therefore, legal rules should be based on an understanding by human of good and evil.

A.A. Frolov believes that further research is needed in this direction, the research which will contribute to "a better understanding of the creative contribution by A.S. Makarenko to the pedagogy, "and which would allow "to finally free him from the charges in "drill", in exaggerating of emotional factor and discipline, of the role of responsibility and punishment in education "[10]. The scientist notes that the first attempt to delve into the legacy of A.S. Makarenko in connection with the ideas of the lawyer-psychologist L.I. Petrazhitskii was made in the Russian Academy of Education, when the monograph "The Upbringing of the Citizen in the Pedagogy of A.S. Makarenko " was published [10]. A.A. Frolov noted that "the most important has appeared here in the center of attention - the ratio of the three fundamentals of the human psyche: mind (knowledge), feelings and will. Particular attention is paid to the motivation of behavior, to the unity of rights and responsibilities, to the emotional and sensual basis of behavior, to the training of the character. The concepts such as formation of a certain "norms" of behavior, the category of moral duty are reveals in the close cooperation of moral consciousness and sense of justice (in their undoubted distinction)" [10]. Such an approach is deeply rooted in the traditions of Russian social thought and pedagogy as, while recognizing value and importance of scientific knowledge, the inseparability of this knowledge from the moral aspect has always been emphasized, as well as its distinguishing between good and evil; according to this tradition the knowledge itself is neutral and can be used for any purpose.

Theoretical conclusions at law by Petrazhitskii were for Makarenko the reference points which helped him to successfully develop (bring up) the legal and moral consciousness of the colonists and the communards. The ideas of lawyer-psychologist suggested him the correct way to carry out educational tasks, namely: education of civil personality traits (qualities). In this regard, it is of interest an extremely important statement by L.I. Petrazhitskii: "In terms of pedagogy, we would recommend to parents and other educators to take care of the development with the children, entrusted to their care, of a strong imperative-attributive mentality, respect for the rights of their peers, seniors..., awareness of sanctity of certain rights and just demand, and so on, but at the same time not to overlook the strengthening of the purely moral principles, including those belonging to the same areas of behavior. Conduct aesthetics is generally a less reliable force for rational improvement of behavior and life in general; it has its fancies and sometimes even very dark side. So to give to aestheticism the first place, or strong predominance in education would be a great and very dangerous mistake. But with the proper development of legal and moral consciousness, the reinforcement of these forces by the duly directed and not-hypertrophied aesthetics, can also be only welcomed, especially if the latter is not limited to purely external forms, but is directed by rational education to the heart and the inside of the behavior, and is in general an eventual ally of the reasonable moral and legal consciousness" [11]. 
This is a very important idea, aimed at criticism of the exclusively external morality, manners of behavior, "aestheticism" of the personality according to Petrazhitskii. Much more important is the inner beauty of a person, the essence of his soul.

Thus, according to L.I. Petrazhitskii, moral consciousness (at first place) as well as sense of justice are the factors of individual behavior and social phenomena. A.S. Makarenko used the ideas of the lawyer-psychologist about attributive strength of consciousness imperative obligation, which provided motivation influence on the behavior of young offenders. When there is an emotional experience (understanding) of outsider obligations towards us (our right with respect to others, duty designing on the other, and its active membership - on our own), then the "motor action of the imperative-attributive emotion has ... a character of encouraging and authority authorizing motives to such behavior, which corresponds to the content of our rights; appropriate behavior seems ... to be sanctioned by the highest authority of the attribute rules" [11].

It should be emphasized that the ideas of L.I. Petrazhitskii about the motives of human actions allowed A.S. Makarenko to find the only true method of influence on the first colonists, namely: categorical, strict requirements on the one hand, and respect for the individual, on the other.

A.S. Makarenko considered it necessary to develop in children the legal psychology. He shared L.I. Petrazhitskii point of view that an active sense of justice affects the character of the citizens, the development of self-esteem and other traits of consciousness opposite to the character "slave soul"; purely moral, unassuming psyche (high ideal psyche) requires pretentious, legal psyche for the healthy development of the character. There is no possibility of healthy ethics without such ethical imperative-attributive foundation, he thought.

The L.I. Petrazhitskii ideas about the motives of human actions, about the moral and legal emotions, about the relationship between morality and law, about the moral consciousness and sense of justice as factors of individual behavior and social phenomena, as well as his own practice, helped A.S. Makarenko to formulate his concept of education of homeland citizen, to create a methodology of educational process. Working with young offenders forced the teacher to seek the levers that would help penetrate deep into the human psyche, consciousness. To do this search he used the following theoretical positions by L.I. Petrazhitskii:

- Emotions - the true motives and drives of our behavior - are bilateral mental acts;

- There is a link between submission actions and emotions aimed at these actions (thus, slander and lies cause negative emotions), that is, the distinction between good and evil is inherent in man;

- Emotion of the duty, being a kind of interference free, obstacle to follow one's inclinations and goals, is a type of principal motivation;

- There are mandatory norms (rights) and attributive norms (moral and legal); mandatory norms are one-sided (imposing under authority a burden on one person, without sharing it with others); as regards the attributive norms they are actually bilateral in nature;

- Imperative-attributive consciousness affects the will and behavior of a person much stronger than imperatives per se; therefore imperative-attributive motivation is more important for the social life from the viewpoint of the pressure behavior of the individual, retention from harmful behavior and instilling the socially necessary behavior;

- An active sense of justice affects the character of the person.

A.S. Makarenko was interested in the problems associated with the sense of justice, free (moral) obligations and legal (juridical) obligations. This interest is reflected in official documents, in which the educator raised the legal issues. For example, after reading the draft charter of child labor agricultural colony, June 20, 1924, A.S. Makarenko wrote to the inspector for protection of childhood of People's Commissariat of Education of the Ukrainian Soviet Socialist Republic that "every colony has the right to produce, exchange, build and contract", that "general rules should provide institutions with the legal framework for economically active educative life "and that " everyday life and labor organization of each of the institutions should be given to themselves"; that "a number of children's internal organization, inner relationships, economic and legal forms - generally the whole charter of the institution should be created by itself. Thereby the charter of each institution should become a kind of mirror that reflects the whole life of the institution" [12].

It's in the educational institutions led by A.S. Makarenko that such internal charter was approved by the whole collective, in other words this charter organically grew out of his needs of the collective and his perceptions of truth. The Charter was the set of laws norms and rules of behavior - which nobody could break. The educator achieved that the most severe forms of colonists' moral neglect were converted "into a gradual and correct process of formation of normal moral experience" [13]. It should be stressed once again that within this normal moral experience the discipline of the individual and the notion discipline in general was considered by the educator as a moral category, as a citizen health. A.S. Makarenko merit is that he created a strong legal community, a democracy which is not formal, but deep in its human essence. And this experience had powerful roots, both national and universal. It is inherently different from the external, institutional "democracy", which is offered to us by other civilizations, even though it uses many forms of this "democracy". This is the relevance of the study and practical application A.S. Makarenko's experience. A strong legal basis and moral conditioning - here are the components on which the civic education of the personality will be built in modern times.

\section{References}

1. Official news portal, available online: URL http://kremlin.ru/events/president/news/16470 (accessed 08.02.2016) 
2. L.N. Belenchuk, E.N. Nikulina, A.V.Ovchinnikov, and E.A. Prokofieva, Reader on the History of National Pedagogy, XIX - early XX century (Moscow, 2012) [In Rus]

3. A.I. Fursov, Forward to the Victory! Russian Success in Retrospect and Prospect (Moscow, 2014) [In Rus]

4. W. Engdahl, Century of War: Anglo-American Oil Politics and the New World Order (Moscow, 2014)

5. Materials of the news portal, available online: URL http://3rm.info/mainnews/61087-igry-v-

demokratiyu-okoncheny-fenita-lya-komediya-vyukatasonov-o-taynom-mezhdunarodnomsoglashenii.html (accessed 08.02.2016

6. A.F. Nikitin, Individual development, 1 (1997) [In Rus]N.I. Eliasberg, Law in School 1 (2005) [In Rus]

7. L.N. Belenchuk, and O.L. Yanushkyavichene, History of Foreign and Russian Pedagogy (Moscow, 2011) [In Rus]

8. The History of Pedagogy and Education. From the Inception of Education in the Primitive Society to the End of the Twentieth Century: A manual for teachers of educational institutions (Moscow, 2001) [In Rus]
9. A.A. Frolov, A.S. Makarenko and L.I. Petrazhitsky, the Ratio of Law and Morality (Pedagogical Aspect) (Samara, 2008) [In Rus]

10. L.I. Petrazhitskii, On the Motives of Human Actions, in Particular the Ethical Motives and their Variations (Sankt-Petersburg, 1904) [In Rus]

11. A.S. Makarenko, Pedagogical Works (Moscow, 1983-1986) [In Rus]

12. S.S. Nevskaya, Citizen Education in Pedagogy of A.S. Makarenko (Moscow, 2006) [In Rus] 